\title{
Inheritance of Resistance to Lettuce Infectious Yellows Virus in Melon
}

\author{
James D. McCreight ${ }^{1}$ \\ U.S. Department of Agriculture, Agricultural Research Service, 1636 East \\ Alisal Street, Salinas, CA 93905-3018
}

Additional index words. cantaloupe, closterovirus, disease, germplasm, Cucumis melo, muskmelon, whitefly, Bemisia tabaci, sweetpotato whitefly, Bemisia argentifolii, silverleaf whitefly

\begin{abstract}
Lettuce infectious yellows virus (LIYV), transmitted by the sweetpotato whitefly, (Bemisia tabaci Genn.), seriously affected melon (Cucumis melo L.) production in the lower desert areas of the southwest United States from 1981 through 1990. Melon plant introduction (PI) 313970 was previously found resistant to LIY V in naturally infected field tests and controlled-inoculation greenhouse tests. Data from $F_{1}$ and segregating generations from crosses of PI 313970 with LIYV-susceptible lines indicated that resistance in this accession is conditioned by a dominant allele at a single locus designated Lettuce infectious yellows (Liy).
\end{abstract}

Sweetpotato whitefly (SPW), and silverleaf whitefly (Bemisia argentifolii Bellows \& Perring) (SLW), have adversely affected yield and quality of a wide range of vegetable and agronomic crops directly through feeding damage or indirectly as virus vectors (Henneberry et al., 1998). Lettuce infectious yellows virus (LIYV), a closterovirus transmitted by the SPW, seriously affected melon production in the lower elevation desert areas of Arizona and California, and the Sonora Desert of Mexico from about 1981 through 1990(Duffus, 1995; Duffus and Flock, 1982; Duffus et al., 1986; Wisler et al., 1998). Foliar symptoms appear 5-8 weeks postinoculation and are characterized by interveinal yellowing and eventual brittleness of the older leaves. Symptoms appear first in the basal (crown) leaves and progress acropetally.

Breeding line WMR 29 and 'Harvest Pride' were reported in 1982 to be nearly asymptomatic in a field test of nine melon cultivars and breeding lines (Mayberry and Johnson, 1982). In a 1988 field test, snake melon was the most resistant of 22 genetically diverse melon genotypes, whereas WMR 29 was not significantly better than LIYV-susceptible 'Top Mark' (McCreight, 1991). In a 1989 field test, PI 313970, breeding line MR-1, and PI 124111 were not significantly better than snake melon (McCreight, 1992). In a 1990 field test,

Received for publication 13 July 1999. Accepted for publication 3 Mar. 2000. I thank J.A. Principe for assistance in the field tests, Patti Fashing for assistance in the greenhouse tests, A. Cortez for virus isolates, and H.-Y Lui and G.W. Wisler for their help in virus confirmation. This research was funded in part by the California Melon Research Board. Mention of a proprietary product in this paper does not constitute endorsement of the product by the U.S. Dept. of Agriculture. The cost of publishing this paper was defrayed in part by the payment of page charges. Under postal regulations, this paper therefore must be hereby marked advertisement solely to indicate this fact.

${ }^{1}$ E-mail address: mccreight@pwa.ars.usda.gov
PI 313970 was asymptomatic, whereas the other entries, including MR-1, PI 124111, and snake melon, expressed severe symptoms (McCreight, 1998).

The SLW is capable of transmitting LIYV under experimental conditions, but the success rate is extremely low (Duffus, 1995). The displacement of SPW by SLW in 1991 in the lower elevation deserts of Arizona and California brought an abrupt end to the LIYV epidemic in these areas (Brown et al., 1992). Because of this sudden change in whitefly species, additional naturally infected field tests for selection of resistance to LIYV were no longer possible.

The resistance to LIYV exhibited by PI 313970 in the 1989 and 1990 field tests was demonstrated in controlled-inoculation greenhouse tests (McCreight, 1998). The objective of this research was to confirm these results and to report inheritance of resistance of PI 313970 to LIYV in greenhouse tests.

\section{Materials and Methods}

Plant materials and culture. PI 313970 was received from the All Union Institute of Plant Industry, Leningrad, in 1966; the original collection was from India (U.S. Dept. of Agriculture, 1969). A sample of the original seeds of PI 313970 was sent in that same year to G.W. Bohn [U.S. Dept. of Agriculture, Agricultural Research Service(USDA-ARS), retired], who increased them in a greenhouse using controlled-pollination (Whitaker and Davis, 1962). This seed stock and a subsequent increase from it were used in the previously reported field and greenhouse tests (McCreight, 1992, 1998) for crosses with LIYV-susceptible melons and in these greenhouse tests

PI 313970 was crossed with 'Top Mark' and AR 5. 'Top Mark' is a widely grown western U.S. shipping-type cantaloupe. AR 5 is a melon aphid-resistant breeding line that is similar to 'PMR 5' (Bohn et al., 1980). The $\mathrm{F}_{2}$,
$\mathrm{F}_{3}$, and backcross families from $\mathrm{F}_{1} \times$ susceptible parents $\left(\mathrm{BC}_{1 \mathrm{~S}}\right)$ and $\mathrm{F}_{1} \mathrm{x}$ resistant parent $\left(\mathrm{BC}_{1 \mathrm{R}}\right)$ generations were produced in a greenhouse. Susceptible and resistant parents, and their offspring, were evaluated for LIYV resistance in a series of greenhouse tests from 1996 through 1998 . Powdery mildew-resistant 'PMR 5' was used as the LIYV-susceptible control in some of the tests because 'Top Mark' is susceptible to powdery mildew, Sphaerothecafuliginea (Schlecht.)Poll., which can mask LIYV symptoms (data not presented).

Seeds were sown in washed sand in $10-\mathrm{cm}$ plastic pots $(\approx 700 \mathrm{~mL})$. Inoculated seedlings were transplanted into $21-\mathrm{cm}$ plastic pots $(\approx 6 \mathrm{~L})$ where they were watered daily as needed with a dilute $(1: 100)$ solution of $20 \mathrm{~N}-20 \mathrm{P}$ $20 \mathrm{~K}$ fertilizer solution.

Virus source and inoculation procedure. The LIYV inoculum source used in these tests was derived from the original LIYV isolate (Duffus et al., 1986). It had been maintained on various hosts since the time of its collection, but was usually maintained in chenopodium (Chenopodium murale L.) or melon (A. Cortez, USDA-ARS, Salinas, Calif., personal communication).

The inoculation procedure changed during the 3 years of these tests. All tests used viruliferous SPW to inoculate candidate melon and chenopodium plants. In the first test of the $F_{1}$ generation, plants were individually inoculated. A clear, plastic, sleeve cage $(10.5 \times 5.0$ $\mathrm{cm})$ was placed over each plant. The top end of each cage was covered with SPW-proof fabric $(\approx 46$ threads $/ \mathrm{cm})$ for confining SPW. Viruliferous SPW were introduced into each cage and allowed to feed for 48 to $72 \mathrm{~h}$, after which they were sprayed with Resmethrin ${ }^{\circledR}\left(\mathrm{PT}^{\circledR}\right.$ 1200 DS Resmethrin; Whitmore Research Laboratories, St. Louis) to kill the SPW and terminate inoculation. Inoculations were done by mass infestation in all subsequent tests. Seedlings were placed in cages $(60 \times 60 \times 60$ $\mathrm{cm}$ ) covered with SPW-proof Dacron ${ }^{\circledR}$ chiffon fabric (28.5 threads per cm; BioQuip, Gardena, Calif.). Viruliferous SPW were introduced daily for several days ( $\leq 7 \mathrm{~d}$ depending upon availability of SPW) in an attempt to infect $100 \%$ of the susceptible check plants. Following mass infestation, plants were sprayed with Resmethrin ${ }^{\circledR} 24 \mathrm{~h}$ prior to being transferred to cages $(90 \mathrm{~cm}$ wide $\times 90 \mathrm{~cm}$ deep $\times 150 \mathrm{~cm}$ high) that were covered with SPW-proof Dacron ${ }^{\circledR}$ chiffon fabric. Each cage contained five plants.

The SPW were reared on virus-free sweetpotato[Ipomoeabatatas (L.) Lam.]plants maintained in SPW-proof fabric-covered cages in a greenhouse. SPW were transferred to LIYV-infected melon or chenopodium leaves using a hand-held vacuum (Cohen et al., 1989) and allowed to feed for $24 \mathrm{~h}$. About 40 viruliferous SPW were then transferred to each plant in the sleeve cage test. For mass infestation, the SPW-infested, virus-infected leaves were placed in a cage with the candidate plants following the initial 24-h virus acquisition period. The SPW-infested source leaves were shaken by hand at the time of transfer, and then daily thereafter, in order to encourage move- 
ment of the SPW to the candidate plants.

Plants were examined weekly for LIYV symptoms beginning 3-4 weeks postinoculation. LIYV symptoms were recorded as present, or absent. Symptom severity was not evaluated.

Confirmation of virus infection. Yellowing due to senescence or chlorosis due to nutritional imbalances may confound the assessment of foliar symptoms of yellowing viruses (Wisler et al., 1998). Generally, melon accessions from India exhibit nutritionalrelated chlorosis in our greenhouse sand culture tests (data not presented). Infection was, therefore, verified by enzyme-linked immunosorbent assays (ELISA) using the "double sandwich" method (Clark and Adams, 1977), except that the coating globulin was used at $1 \mu \mathrm{g} \cdot \mathrm{mL}^{-1}$ and enzyme-conjugated globulin was at a dilution of 1:400 or 1:800. The threshold for the tests reported herein was $2 \times$ the optical density of the healthy control after correction for the buffer (McCreight, 1998).

Symptom expression of inoculated plants was verified also by serial transfer of LIYV from selected melon plants to chenopodium plants in all but one of the tests. The procedure used was similar to the first tests in which the melons were individually inoculated. Symptom expression and ELISA data were recorded from the serially inoculated chenopodium. In most cases, serial transfers were made from melon plants that were asymptomatic or that were negative in ELISA tests when they were expected to be susceptible (escapes). Serial transfers were made from all candidate plants in three $\mathrm{BC}_{1 \mathrm{~S}}$ families because of the high frequency of susceptible plants $(50 \%)$ expected in these families. Serial transfers were not made from PI 313970 or $\mathrm{BC}_{1 \mathrm{R}}$ plants because all were expected to be resistant. Chi-square analyses of the segregation data were completed using the correction factor of Yates (1931).

\section{Results}

'Top Mark' and 'PMR 5' are susceptible to LIYV based on previous field and greenhouse tests (McCreight, 1991, 1992, 1998). 'Top Mark', 'PMR 5', and AR 5 were susceptible to LIYV in these tests, but the number of symptomatic plants ranged from as few as one of nine inoculated $(11 \%)$ to as many as 12 of 15 inoculated $(80 \%)$ plants. ELISA data indicated a similar range in the frequency of infection $(11 \%$ to $100 \%)$. Results are not presented from the sleeve cage inoculated test, where the frequency of infection of the susceptible checks was $<75 \%$.

PI 313970 was, with two exceptions, completely resistant in these tests. One of these exceptions was symptomatic, but the ELISA test was negative; the other was asymptomatic and the ELISA test was positive (Table 1). In a previous report, 1 of 26 plants of PI 313970 in three greenhouse tests was symptomatic 8 weeks postinoculation, but the ELISA test was negative (McCreight, 1998). PI313970 has exhibited resistance in two field tests and nine greenhouse tests. However, an occasional plant of this accession may appear symptomatic, or have a positive ELISA for LIYV.

Twenty-four individuals in three $\mathrm{F}_{1}$ families were resistant to LIYV (Table 1). No maternal effects were detected (data not presented). The segregation of resistant and susceptible plants in an $\mathrm{F}_{2}$ family fit a 3:1 ratio $(P=0.30)$. These results indicate that the resistance observed in PI 313970 is conditioned by a dominant allele at a single locus.

Three $\mathrm{F}_{3}$ families confirmed the possible genotypes of their respective $\mathrm{F}_{2}$ parents (Table 1). Resistant $F_{2}$ individuals are expected to produce $\mathrm{F}_{3}$ families that either segregate 3 resistant : 1 susceptible, or are homozygous resistant in a single locus, dominant allele model. One of the $\mathrm{F}_{3}$ families was completely resistant to LIYV, whereas another had one symptomatic plant that was positive for LIYV in ELISA. Susceptible $F_{2}$ individuals are expected to produce $\mathrm{F}_{3}$ families that are homozygous susceptible. The one $\mathrm{F}_{3}$ family that was derived from a susceptible $\mathrm{F}_{2}$ individual was susceptible; six of eight inoculated plants were positive in ELISA. Chi-square analysis indicated that the frequency of infection of this susceptible $\mathrm{F}_{3}$ family $(75 \%)$ did not differ from that of 'PMR 5' $(88 \%)$, the susceptible control $(P=0.54)$.

As predicted by the single locus model, the $\mathrm{BC}_{1 \mathrm{R}}$ was completely resistant to LIYV (Table 1). The three $\mathrm{BC}_{1 \mathrm{~S}}$ families segregated for resistance. In one test, two $\mathrm{BC}_{1 \mathrm{~S}}$ family segregations fit a $1: 1$ ratio $(P=0.08$ and 0.46 , respectively). However, in a second test, two of the three $\mathrm{BC}_{\mathrm{S}}$ families did not fit the expected $1: 1$ ratio $(P=0.04,0.01$, and 0.12$)$ (Table 1).

\section{Discussion}

Collectively, the $\mathrm{F}_{1}, \mathrm{~F}_{2}, \mathrm{~F}_{3}$, and backcross segregations indicate that resistance to LIYV in PI 313970 is conditioned by a dominant allele at a single locus. This locus is designated Lettuce infectious yellows and symbolized Liy in accordance with the nomenclature rules for cucurbits (Cucurbit Genetics Cooperative, 1999).
Greenhouse tests were used for all of the work reported herein although they have several inherent problems. First, LIYV is not mechanically transmissible (Duffus et al., 1986). Second, SPW must be reared on virusfree hosts under natural light in order to ensure the availability of large numbers of SPW for inoculations. This requires a significant amount of greenhouse space, and measures must be established to confine the insects and to control escapes that infest nontest hosts in the greenhouse. Third, SPW are fragile; they are easily injured during transfer from their colonies to virus source plants and subsequently to candidate plants. Large numbers of healthy SPW are needed to achieve a modest degree of success in inoculating plants with LIYV (Duffus et al., 1986). These problems ensure difficulty in achieving consistently high rates (number of infected plants/ number of inoculated plants) of infection with LIYV. Fourth and finally, melon plants grown long enough for symptom expression to occur ( $\approx 8$ weeks postinoculation) require much space for proper growth. For these reasons, the research reported herein was done in a series of relatively small tests. The erratic infection rates and poor symptom expression following LIYV infection in a greenhouse necessitated the use of ELISA and serial transfers from inoculated melon plants to chenopodium in order to confirm the melon infection data (McCreight, 1998). Nevertheless, the abrupt transition from the SPW to the SLW in 1991 (Brown et al., 1992) left no naturally-infected alternative to greenhouse testing for resistance to LIYV.

The feasibility of using controlled inoculations in a greenhouse to transfer resistance from PI 313970 to other melon genotypes was demonstrated, notwithstanding the problems enumerated above. Free-movement of SPW from virus source plants to candidate plants in segregating populations may facilitate $100 \%$ infection of the susceptible plants (susceptible check and segregating families). An isolated (spatially or by using SPW-proof barriers) greenhouse that permitted movement of viruliferous SPW would be ideal for this purpose. A facility of adequate size would

Table 1. Reactions of susceptible and resistant melons, and their $\mathrm{F}_{1}, \mathrm{~F}_{2}, \mathrm{~F}_{3}$, and $\mathrm{BC}_{1}$ families, to lettuce infectious yellows virus in four greenhouse tests.

\begin{tabular}{|c|c|c|c|c|c|}
\hline Entry & Phenotype $^{z}$ & Resistant $^{\mathrm{y}}$ & Susceptible & Expected ratio & $P$ \\
\hline Top Mark (TM) & $\mathrm{S}$ & 0 & 7 & & \\
\hline PMR 5 & S & 5 & 29 & & \\
\hline PI 313970 (PI) & $\mathrm{R}$ & 37 & 1 & & \\
\hline $\mathrm{F}_{1} \mathrm{PI} \times \mathrm{AR} 5$ & & 24 & 0 & & \\
\hline $\mathrm{F}_{2} \mathrm{TM} \times \mathrm{PI}$ & & 16 & 9 & $3: 1$ & 0.30 \\
\hline $\mathrm{F}_{3} \mathrm{TM} \times \mathrm{PI}$ & $\mathrm{R}$ & 19 & 1 & $1: 0$ or $3: 1$ & \\
\hline $\mathrm{F}_{3} \mathrm{TM} \times \mathrm{PI}$ & $\mathrm{R}$ & 16 & 0 & $1: 0$ or $3: 1$ & \\
\hline $\mathrm{F}_{3} \mathrm{TM} \times \mathrm{PI}$ & S & 2 & 6 & $0: 1$ & \\
\hline $\mathrm{BC}_{1 \mathrm{R}}(\mathrm{TM} \times \mathrm{PI}) \mathrm{PI}$ & & 18 & 0 & $1: 0$ & \\
\hline $\mathrm{BC}_{1 \mathrm{~S}} \mathrm{TM}(\mathrm{PI} \times \mathrm{TM})$ & & 9 & 2 & $1: 1$ & 0.08 \\
\hline $\mathrm{BC}_{1 \mathrm{~S}}(\mathrm{TM} \times \mathrm{PI}) \mathrm{TM}$ & & 10 & 6 & $1: 1$ & 0.46 \\
\hline $\mathrm{BC}_{1 \mathrm{~S}}(\mathrm{PI} \times \mathrm{AR} 5) \mathrm{AR} 5$ & & 14 & 4 & $1: 1$ & 0.04 \\
\hline $\mathrm{BC}_{1 \mathrm{~S}} \mathrm{TM}(\mathrm{PI} \times \mathrm{TM})$ & & 15 & 3 & $1: 1$ & 0.01 \\
\hline $\mathrm{BC}_{1 \mathrm{~S}}(\mathrm{TM} \times \mathrm{PI}) \mathrm{TM}$ & & 14 & 6 & $1: 1$ & 0.12 \\
\hline
\end{tabular}

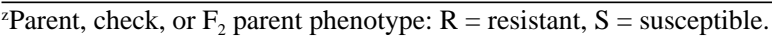

'Includes resistant and escape plants. 
permit testing of larger populations than those used in this study.

The long period from inoculation to positive identification of all infected plants and the number of plants that have to be carried through this period may be reduced through the application of one or more laboratory procedures. Inclusion body staining permits identification and roguing of infected plants at a much earlier stage of growth than symptom expression or ELISA (Hoefert et al., 1992). Dot-blot hybridization using RT-PCRbased probes (Tian et al., 1996), which is more sensitive than ELISA, to identify susceptible plants may eliminate the need for serial transfer to chenopodium. These laboratory procedures and serial transfers to chenopodium will reveal asymptomatic individuals, but they are subject to the same type of error in identifying infected plants (McCreight, 1998). Moreover, they will not identify escapes.

Escapes remain problematic for a breeder intent on transferring LIYV resistance from PI 313970 to elite germplasm. They result in unintended selection of susceptible individuals for subsequent crossing. Thus, the advantage of a dominant allele for resistance to LIYV cannot be fully realized in a backcross program designed to transfer LIYV resistance from PI 313970 to an orange-fleshed, western shipping-type melon. Each putative resistant selection must be self-pollinated as well as backcrossed to the recurrent parent to unequivocally distinguish genetically resistant individuals (Liyliy) from genetically susceptible escapes (liyliy). Testing of self-pollinated families for resistance to LIYV permits identification of liyliy individuals and complete classification of backcross families.

Mechanical, SLW-independent, inoculation procedures may provide consistently high infection rates. Current gene gun technology is efficacious for inoculating melons with geminiviruses (Gilbertson et al., 2000). Agrobacterium-based inoculation is another potential technique (Hou et al., 1998). However, a substantial amount of work remains to be done before these techniques can be used with LIYV.

Identification of a tightly linked $(<5 \mathrm{cM})$ marker (phenotypic, isozyme, or molecular) would be useful in reducing the cost and uncertainty of selecting individuals that are resistant to LIYV. Co-dominant polymerase chain reaction-based markers offer the advantage of being able to discern homozygous resistant (LiyLiy) from heterozygous resistant (Liyliy) individuals. Strategic use of marked-assisted selection might prove effective for selection of homozygous resistant individuals (LiyLiy) during inbreeding.

\section{Literature Cited}

Bohn, G.W., A.N. Kishaba, and J.D. McCreight. 1980. WMR 29 muskmelon breeding line. HortScience 15:539-540.

Brown, J.K., H.S. Costa, and F. Laemmlen. 1992. First report of whitefly-associated squash silverleaf disorder of Cucurbita in Arizona and of white streaking disorder of Brassica species in Arizona and California. Plant Dis. 76:426.

Clark, T.M. and A.M. Adams. 1977. Characteristics of the microplate method of enzyme-linked immunosorbent assay for the detection of plant viruses. J. Gen. Virol. 34:375-483.

Cohen, S., J.E. Duffus, R. Perry, and R. Dawson. 1989. A collection and marking system suitable for epidemiological studies on whiteflyborne viruses. Plant Dis. 73:765-768.

Cucurbit Genetics Cooperative, Gene List Committee. 1999. Gene nomenclature for the Cucurbitaceae. Cucurbit Genet. Coop. Rpt. 22:78.

Duffus, J.E. 1995. Whitefly transmitted yellowing viruses of the Cucurbitaceae, p. 12-16. In: G.E. Lester, and J.R. Dunlap (eds.). Cucurbitaceae '94: Evaluation and enhancement of cucurbit germplasm, 1-4 Nov., South Padre Island, Texas. Gateway Printing and Office Supply, Edinburg, Texas.

Duffus, J.E. and R.A. Flock. 1982. Whitefly-transmitted disease complex of the desert southwest. Calif. Agr. 36(11-12):4-6.

Duffus, J.E., R.C. Larsen, and H.-Y. Liu. 1986. Lettuce infectious yellows virus-A new type of whitefly-transmitted virus. Phytopathology 76:97-100.

Gilbertson, R.L., E.T. Natwick, T. Turini, and K.S. Mayberry. 2000. Cucurbit leaf crumple, a new geminivirus. Plant Dis. 84:488.
Henneberry, T.J., N.C. Toscano, and S.J. Castle. 1998. Bemisia sp. (Homoptera: Aleyrodidae) in the United States: History, pest status, and management. Recent Res. Dev. Entomol. 2:151-161.

Hoefert, L.L., J.D. McCreight, and R.D. Christie. 1992. Microwave enhanced staining for plant virus inclusions. Biotechnic and Histochem. 67:40-44.

Hou, Y.-M., E.J. Paplomatas, and R.L. Gilbertson. 1998. Host adaptation and replication properties of two bipartite geminiviruses and their pseudorecombinants. Microbe Plant Mol. Interactions 11:208-217

Mayberry, K.S. and H. Johnson, Jr. 1982. Cantaloupe variety trial results. Imperial Agr. Briefs, Coop. Ext., Univ. Calif., Aug. 1982:6-7.

McCreight, J.D. 1991. Potential sources of resistance to lettuce infectious yellows in melon. Cucurbit Genet. Coop. Rpt. 14:51-52.

McCreight, J.D. 1992. Screening for lettuce infectious yellows virus resistance in melon, p. 160 162. In: R.W. Doruchowski, E. Kozik, and K. Niemirowicz-Szczytt (eds.). Fifth Eucarpia cucurbitaceae symposium, 27-31 July, Res. Instit. of Veg. Crops Skierniewice and Warsaw Univ. of Agriculture Warsaw, Poland.

McCreight, J.D. 1998. Breeding melons for resistance to lettuce infectious yellows virus, $\mathrm{p}$. 241-247. In: J.D. McCreight (ed.). Cucurbitaceae '98: Evaluation and enhancement of cucurbit germplasm, 30 Nov. to 4 Dec., Asilomar, Calif. ASHS Press, Alexandria, Va.

Tian, T., V.A. Klaassen, J. Soong, G. Wisler, J.E. Duffus, and B.W. Falk. 1996. Generation of cDNAs specific to lettuce infectious yellows closterovirus and other whitefly-transmitted viruses by RT-PCR and degenerate oligonucleotide primers corresponding to the closterovirus gene encoding the heat shock protein 70 homolog. Phytopathology 86:1167-1173.

U.S. Dept. of Agriculture. 1969. Plant Inventory No. 174. Plant material introduced 1 Jan. to 31 Dec. 1966 (Nos. 310336 to 317903). U.S. Dept. Agr., Washington, D.C.

Whitaker, T.W. and G.N. Davis. 1962. Cucurbits: Botany, cultivation and utilization. Interscience Pub., New York.

Wisler, G.C., J.E. Duffus, H.-Y. Liu, and R.-H. Li 1998. Ecology and epidemiology of whitefly transmitted closteroviruses. Plant Dis. 82:270280.

Yates, F. 1931. Contingency tables involving small numbers and the $\chi^{2}$ test. J. Royal Stat. Soc. 1:215-235 (Suppl.). 